\title{
Iron deficiency and neurotransmitter syntbesis and function
}

\author{
By M. B. H. Youdim* and A. R. Green, MRC Clinical Pharmacology Unit, \\ Radcliffe Infirmary, Oxford $O X_{2} 6 H E$
}

There has been little work on the effects of iron-deficiency on brain metabolism and function despite the fact that $\mathrm{Fe}$ deficiency is the most common nutritional disorder in the world (Garby, 1973; Kossner \& Kalk, 1973).

$\mathrm{Fe}$ is present in the brain in relatively large amounts and is particularly concentrated in the basal ganglia (Cumings, 1948, 1968; Hallgren \& Sourander, 1958; Harrison, Netsky \& Brown, 1968). Furthermore it's concentration appears to be independent of the liver Fe stores (Hallgren \& Sourander, 1958; Dallman, 1974).

It has been suggested that $\mathrm{Fe}$ is a cofactor for tyrosine hydroxylase (EC 1.I4.1 6.2) (Sourkes, 1972) and tryptophan hydroxylase (EC I.I3.I I.II) (Ichiyama, Nakamura, Nishizuka \& Hayashi, 1968; Lovenberg, Jequier \& Sjoerdsma, 1968; Youdim, Hamon \& Bourgoin, 1975), enzymes involved in the formation of catecholamines and 5 -hydroxytryptamine $(5-\mathrm{HT})$ respectively. The activity of the monoamine degradative enzyme monoamine oxidase (EC 1.4.3.4; $\mathrm{MAO}$ ) has also been shown to be lowered in the tissues of both humans and rats with $\mathrm{Fe}$ deficiency anaemia (Symes, Sourkes, Youdim, Birnbaum \& Gregoriadis, 1969; Voorhess, Stuart, Stockman \& Oski, 1975; Youdim, Woods, Mitchell, GrahameSmith \& Callender, I975; Youdim, Grahame-Smith \& Woods, 1976).

We have now investigated the effects of Fe deficiency in rats on the activity of various monoamine-metabolizing enzymes in the brain. The functional activity of the monoamine neurotransmitter systems has also been investigated by measuring the behavioural responses of the rats to increased brain 5-HT and dopamine (DA) receptor stimulation.

\section{Preparation of Fe-deficient rats}

Male Sprague-Dawley rats (Anglia Laboratory Animals, Huntingdon), initial weight $80+20 \mathrm{~g}$ (mean $+\mathrm{SEM}$ ) were made $\mathrm{Fe}$ deficient by feeding on a semisynthetic diet of milk powder low in Fe (McCall, Newman, O'Brien, Valberg \& Witts, 1962) and distilled water. Control rats were given tap-water and the milkpowder diet with ammonium ferrous sulphate (I.3 mg/g diet) added. The $\mathrm{Fe}-$ deficient group were given ad lib. access to the diet while the control group had their food intake restricted to that of the Fe-deficient group. After 5 weeks the

-Present address: Dept of Pharmacology, School of Medicine, Israel Institute of TechnologyTechnion, Haifa, Israel. 
animals were judged to be $\mathrm{Fe}$ deficient (haemoglobin $(\mathrm{g} / \mathrm{l})$ : control group $14 \mathrm{I} \pm 4.4$ $(n$ I 6$)$, Fe-deficient group $55 \cdot 5 \pm 4 \cdot 2(n 22))$.

\section{Distribution of non-haem-Fe in the brain}

The regional distribution of non-haem-Fe is reported in Table $I$ and in agreement with Dallman, Simes \& Manies (1975) a mean brain concentration of $0.074 \mu \mathrm{g}$ non-haem-Fe/mg protein was found. The Fe-deficient rats had a mean non-haem-Fe concentration of $0.030 \mu \mathrm{g} / \mathrm{mg}$ protein, showing a $60 \%$ reduction. The distribution (\%) between the subcellular functions was unchanged in $\mathrm{Fe}$ deficiency showing that there are no specific effects on this distribution.

Table 1. Distribution of non-haem-iron in various areas of rat brain

(The results shown are mean values with their standard errors for six animals)

Brain areas

Cerebellum

Brain stem

Caudate nucleus

Amygdala

Cerebral cortex

Hypothalamus

$\begin{array}{lc}\text { Mean } & \text { SE }(\mu \mathrm{g} / \mathrm{mg} \text { protein }) \\ 0.075 & 0.008 \\ 0.052 & 0.008 \\ 0.092 & 0.036 \\ 0.05^{8} & 0.005 \\ 0.050 & 0.003 \\ 0.076 & 0.030\end{array}$

\section{Monoamine-metabolizing enzymes during $F e$ deficiency}

In rats with haemoglobin values of $69 \pm 6 \mathrm{~g} / 1$ no decrease in tryptophan hydroxylase activity was found; nor was brain MAO activity lowered even though there was a large decrease in the activity of this enzyme in the liver, heart and adrenal gland (though not the spleen) (Fig. I).

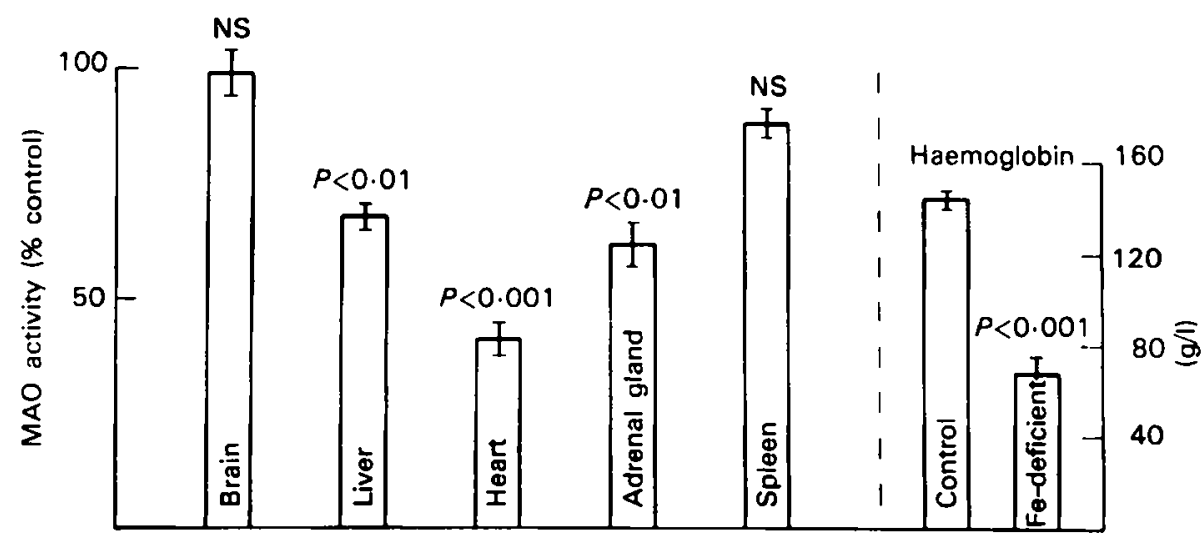

Fig. 1. The effect of iron-deficiency on rat tissue monoamine oxidase ( $E C$ r.4.3.4) activity. The activity was measured in tissue homogenates with kynuramine as substrate: NS, not significant. Enzyme activity was measured in tissues of animals which had been fed on an Fe-deficient or Feadequate (control) diet for at least 5 weeks. 
Brain, liver and heart aldehyde dehydrogenase ( $E C$ r.2.1.3) was also unaltered in these animals. In a group of rats made severely $\mathrm{Fe}$ deficient by keeping them on the Fe-deficient diet for 9 weeks (haemoglobin $45 \pm 6 \mathrm{~g} / \mathrm{l}$ ) there was still no decrease in tryptophan hydroxylase activity, although brain MAO showed a small but statistically significant decrease in activity $(15 \%)$. The flavoprotein-containing succinate dehydrogenase ( $E C$ r.3.99.1; SDH) also showed little change in the brain of these animals although the activity in peripheral tissues was markedly decreased.

The activity of brain enzymes which may be $\mathrm{Fe}$ dependant appear therefore to be very resistant to the effects of $\mathrm{Fe}$ deficiency. $\mathrm{Fe}$ is therefore either still present in sufficient quantities to act as a cofactor, or the enzymes do not require $\mathrm{Fe}$ (which seems to be unlikely in view of the big changes seen in the peripheral activity of $\mathrm{MAO}$ and $\mathrm{SDH}$ ) or is bound in some form which simple nutritional deficiency will not alter.

\section{Effects of Fe deficiency on the functional activity of brain 5-HT and DA}

Administration of a MAO inhibitor (e.g. tranylcypromine) followed by Ltryptophan results in rats displaying various behavioural changes, one feature of which is hyper-reactivity, which can be measured on Animex activity meters (Grahame-Smith, 197 $a$ ). Previous studies have suggested that the extent of hyperactivity is proportional to the rate of increase in 5 -HT synthesis and 'spillover' into functional activity in the brain (see Green \& Grahame-Smith, 1976). A similar behavioural model can be elicited by an injection of tranylcypromine and Ldopa, a procedure which increases brain DA concentration and this activity has been used as an index of brain DA functional activity (Green \& Kelly, 1976). By using these behavioural models together with measurement of activity after injection of the putative $5-\mathrm{HT}$ agonist 5 -methoxy-N,N-dimethyl-tryptamine (5MeODMT) or the DA-releasing drug amphetamine or DA agonist apomorphine, changes in both pre- and post-synaptic monoamine function can be assessed.

After tranylcypromine-L-tryptophan administration, Fe-deficient rats show much less response than control animals (Fig. 2). However, the rate of brain $5-\mathrm{HT}$ accumulation and $5-\mathrm{HT}$ synthesis was the same in both groups (Table 2) supporting the finding that tryptophan hydroxylase activity is unchanged. Endogenous brain 5-HT correlations were decreased in Fe deficiency perhaps due to decreased $5-\mathrm{HT}$ binding and storage at the nerve ending, since $\mathrm{Fe}$ has been shown to be involved in this process (Tamir, Klein \& Rapport, 1976). The decreased activity appears to be due to post-synaptic changes since the response to 5-MeODMT was also inhibited (Table 3).

There were also alterations in DA function, the behavioural responses to tranylcypromine-dopa, methamphetamine and apomorphine being inhibited (Table 3) although again there was no alterations in DA accumulation (Table 4). The biochemical evidence and the changed apomorphine response again point to a post-synaptic change. We were not however, able to detect any alteration in DAsensitive adenylate cyclase ( $E C$ 4.6.I.I) activity. 


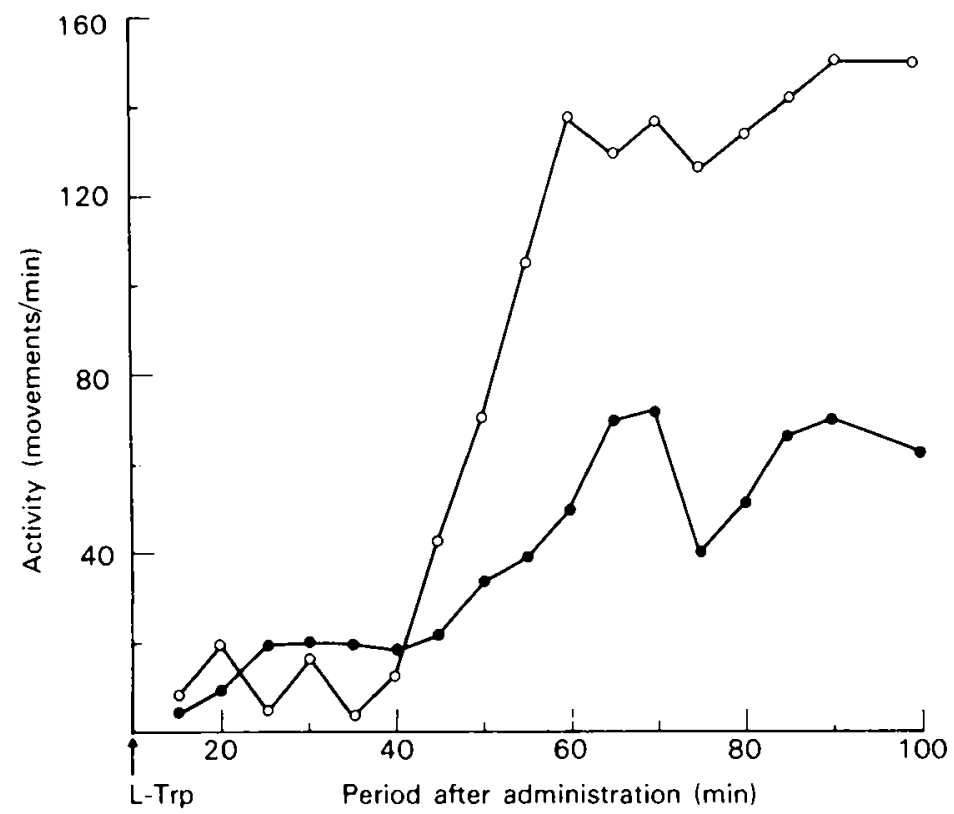

Fig. 2. The behavioural effect (activity; movements/min) of L-tryptophan (L-Trp) given after administration of tranylcypromine (monoamine oxidase ( $E C$ 1.4.3.4) inhibitor). Rats were injected with tranylcypromine $(20 \mathrm{mg} / \mathrm{kg})$ and L-Trp $(100 \mathrm{mg} / \mathrm{kg})$ was given $30 \mathrm{~min}$ later. $(\mathcal{O}-)$, Control; (-), Fe-deficient. Statistical cvaluation is given in Table 3 .

Table 2. The effect of iron deficiency on the synthesis of rat brain 5hydroxytryptamine $(5-H T)$

(The results shown are mean values with their standard errors for no. of observations given in parentheses; results are expressed as $\mu \mathrm{g} / \mathrm{g}$ brain wet weight. The rate of 5 -HT synthesis was determined by the accumulation of $5-\mathrm{HT}$ in excess of the control value during $60 \mathrm{~min}$ after injection of tranylcypromine (a monoamine oxidase ( $E C$ 1.4.3.4) inhibitor). Haemoglobin concentrations in these rats are given in Table 4. 5-HT accumulation was measured $60 \mathrm{~min}$ after injection of Ltryptophan (100 mg/kg) with tranylcypromine $(20 \mathrm{mg} / \mathrm{kg}$ ) being given $30 \mathrm{~min}$ before the tryptophan)

Brain tryptophan $(\mu \mathrm{g} / \mathrm{g})$

Brain 5-HT ( $\mu \mathrm{g} 5-\mathrm{HT} / \mathrm{g})$

Brain 5-HT 60 min after tranylcypromine ( $\mu \mathrm{g} 5-\mathrm{HT} / \mathrm{g})$

Rate of 5 -HT synthesis

( $\mu \mathrm{g} 5-\mathrm{HT} / \mathrm{g}$ per h)

5-HT accumulation after

tranylcypromine-L-tryptophan

$(\mu \mathrm{g} 5-\mathrm{HT} / \mathrm{g})$

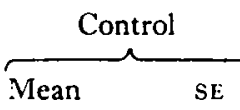

$3 \cdot 33$

$0.3^{8}$

$0.26(4)$

$0.02(6)$

0.51

$0.02 \quad(4)$

0.13

0.095

0.07 (II)

0.91

$0.06(7)$

- Different from control values: $P<0 \cdot 0 \mathrm{r}$. 
Whether these changes are occurring because of a change in DA receptor function (although perhaps not the adenylate cyclase system) or the function of another neuronal system modulating DA function cannot, at present, be stated.

When the Fe-deficient rats were given the $\mathrm{Fe}$ diet for $\mathbf{8} \mathrm{d}$ their responses to tranylcypromine-L-tryptophan and tranylcypromine-L-dopa returned to normal. The haemoglobin value had also increased $(122 \pm 6 \cdot 4 \mathrm{~g} / \mathrm{l})$.

We also confirmed the finding of Glover \& Jacobs (1972), that there is an altered pattern of spontaneous activity in Fe-deficient rats, confirming that they are less active during the dark period (Table 3 ).

Table 3. The effect of iron deficiency on the behavioural response (activity; no. of movements) of rats to various drugs

(The results shown are mean values with their standard errors for no. of observations given in parentheses. Activity was measured on groups of three rats with an Animex activity meter sensitivity and tuning: $30 \mu \mathrm{A}$ ) as described elsewhere (Grahame-Smith, 197I)).

During 90 min after L-Trp

During $60 \mathrm{~min}$ after $\mathrm{L}$-dopa

During $40 \mathrm{~min}$ after 5 -MeODMT

During $90 \mathrm{~min}$ after methamphetamine

During $40 \mathrm{~min}$ after apomorphine

Activity during overnight period

(18.00 hours-10.00 hours)

$\begin{array}{rr}\text { Mean } & \text { SE } \\ 4300 & 66 \text { I (4) } \\ 4576 & 671(4) \\ 2885 & 240(3) \\ 8977 & 1145(4) \\ 3282 & 385(4) \\ 33690 & 2791(3)\end{array}$

\begin{tabular}{|c|c|}
\hline \multicolumn{2}{|c|}{ Fe-deficient } \\
\hline Mean & $\mathrm{SE}$ \\
\hline 1682 & $304(4)^{\bullet}$ \\
\hline 1971 & $786(3)^{\bullet \bullet}$ \\
\hline 1335 & $410(3)^{60}$ \\
\hline $\begin{array}{l}5093 \\
1488\end{array}$ & $\begin{array}{r}1188(3)^{\cdots} \\
642(3)^{\cdots}\end{array}$ \\
\hline 19395 & $2230^{-}$ \\
\hline
\end{tabular}

L-Trp, L-tryptophan; 5-MeODMT, 5-methoxy-N,N-dimethyltryptamine. Different from control values: $* P<0.01, \cdots P<0.02, \cdots \bullet P<0.05$.

Table 4. The effect of iron deficiency on rat brain catecholamine concentrations $(\mu g / g$ brain wet weight) and on haemoglobin $(g / l)$

(The results shown are mean values with their standard errors for no. of observations in parentheses. Accumulation of dopamine and noradrenaline was measured $60 \mathrm{~min}$ after injection of L-dopa ( $50 \mathrm{mg} / \mathrm{kg}$ ), tranylcypromine $(20 \mathrm{mg} / \mathrm{kg}$ ) having been given $30 \mathrm{~min}$ before the L-dopa).

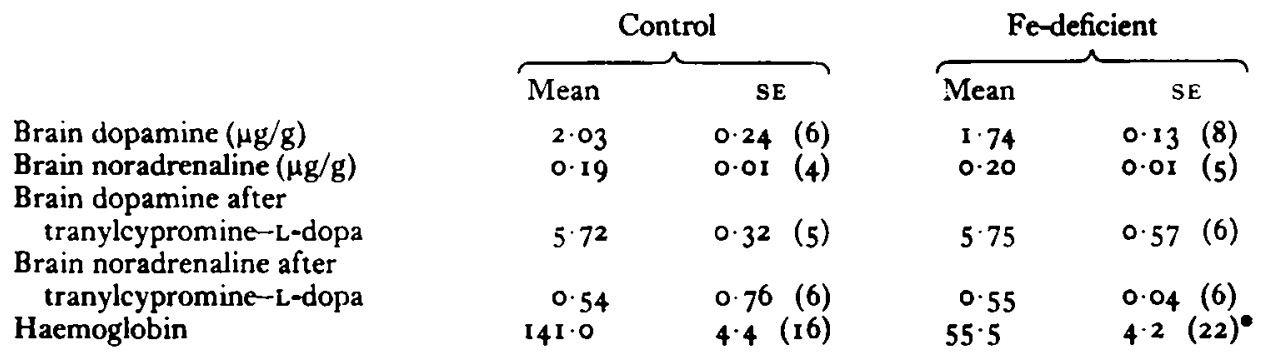

-Different from control values: $P<0.001$. 


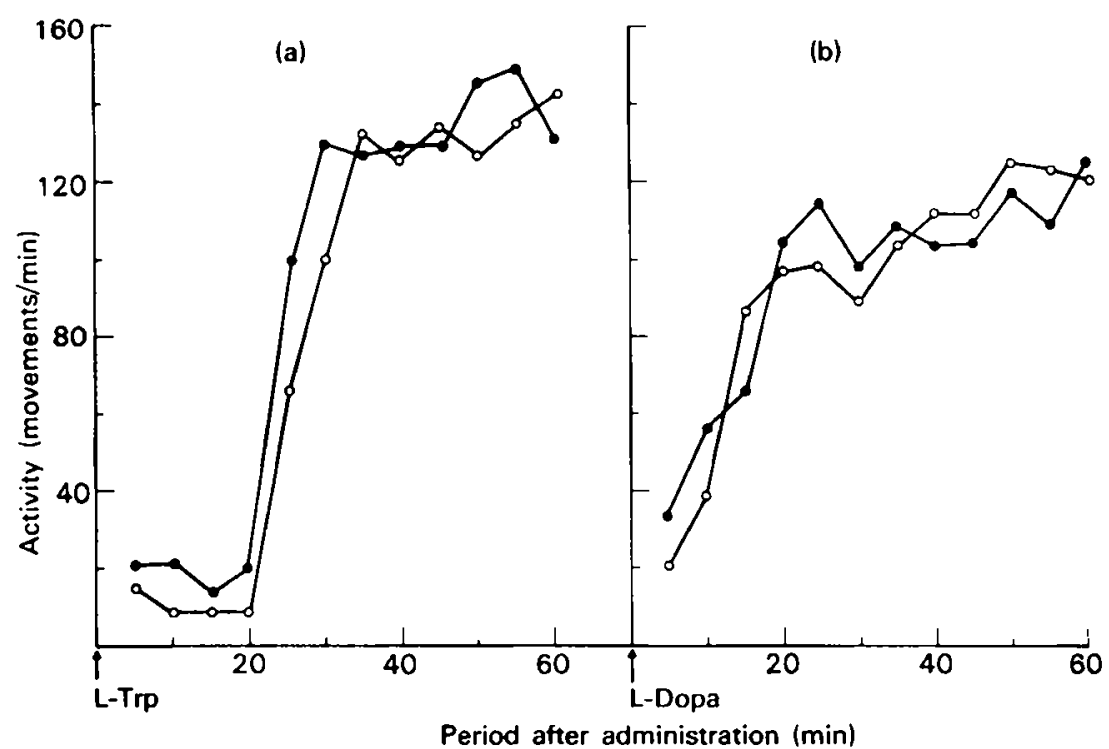

Fig. 3. The behavioural effect (activity; movements/min) of injecting (a) l.-tryptophan (LTrp) or (b) L-dopa after a dose of tranylcypromine (monoamine oxidase (EC I.4.3.4) inhibitor) on hyperactivity in iron-deficient rats given an Fe-adequate diet. Fe-deficient rats (haemoglobin $69 \pm 5 \mathrm{~g} / \mathrm{l}$ ) were placed on $\mathrm{Fe}$-adequate diet for $8 \mathrm{~d}$ and then injected with tranylcypromine $(20 \mathrm{mg} / \mathrm{kg})$ and, $30 \mathrm{~min}$ later, either L-Trp (100 mg/kg) or L-dopa $(50 \mathrm{mg} / \mathrm{kg})$. (O-O), Control; $(-\mathrm{O})$, $\mathrm{Fe}$ deficient.

\section{Conclusions}

We cannot exclude the possibility that the effects of the anaemia or changes in muscle activity are responsible for the changes seen. They are, however, unlikely for several reasons. If the lowered activity were due to an oxygen deficit because of the anaemia, then the activity would have decreased as the experiment progressed. However the lowered responses continue for more than $2 \mathrm{~h}$ after tryptophan injection and increase with the period of time after injection. Dallman (1974) has reported that $\mathrm{Fe}$-deficiency does not alter isolated muscle function and Edgerton, Bryant \& Gillespie (1972) did not demonstrate a relationship between physical performance and muscle content of myoglobin and cytochromes.

The neurotransmitters $5-\mathrm{HT}, \mathrm{DA}$ and noradrenaline are intimately involved in the regulation of mood and neuronal activity. In view of the prevalence of $\mathrm{Fe}$ deficiency in the world, particularly young children (Pollitt \& Leibel, I976) we suggest the long-term effects of Fe deficiency on brain neuronal systems should be further investigated.

\section{REFERENCES}

Cumings, J. N. (1948). Brain 71, 410.

Cumings, J. N. (1968). F. clin. Path. 21, I.

Dallman, P. R. (1974). Iron in Biochemistry and Medicine, pp. 437-475. London: Academic Press. 
Dallman, P. R., Simes, M. A. \& Manies, E. L. (1975). Br. F. Haemat. 31, 209.

Edgerton, V. R., Bryant, S. L. \& Gillespie, C. A. (1972). Y. Nutr. 102, $3^{81 .}$

Garby, L. (1973). Clin. Haemat. 2, 245.

Glover, J. \& Jacobs, A. (1972). Br. med. J. ii, 627.

Grahame-Smith, D. G. (1971). Y. Neurochem. 18, 1053 .

Green, A. R. \& Grahame-Smith, D. G. (1976). Nature, Lond. 260, 487.

Green, A. R. \& Kelly, P. H. (1976). Br. F. Pharmac. 57, I4I.

Hallgren, B. \& Sourander, P. (1958). F. Neurochem. 3, 4 1.

Harrison, W. W., Netsky, M. G. \& Brown, M. D. (1968). Clinica chim. Acta 21, 55.

Ichiyama, A., Nakamura, S., Nishizuka, Y. \& Hayashi, O. (rg68). Adv. Pharmac. 6A, 5.

Kossner, J. \& Kalk, L. (1973). Strategy for Evaluating Health Services. Washington, DC: National Academy of Sciences.

Lovenberg, W., Jequier, E. \& Sjoerdsma, A. (1968). Adr. Pharmac. 6A, 21.

McCall, M. G., Newman, G. E., O'Brien, J. R. P., Valberg, L. S. \& Witts, L. J. (1962). Br. F. Nutr. $16,297$.

Pollitt, E. \& Leibel, R. L. (1976). F. Pediat. 88, 372.

Sourkes, T. L. (1972). Basic Neurochemistry, pp. $5^{81}$-606. Boston: Little Brown \& Co.

Symes, A. L., Sourkes, T. L., Youdim, M. B. H., Birnbaum, H. \& Gregoriadis, G. (1969). Can. J. Biochem. 47, 999 .

Tamir, H., Klein, A. \& Rapport, M. B. (1976). F. Neurochem. 26, 871 .

Voorhess, M. L., Stuart, H. H., Stockman, J. A. \& Oski, F. A. (1975). F. Pediat. 86, 542.

Youdim, M. B. H., Hamon, M. \& Bourgoin, S. (1975). J. Neurochem. 25, 407.

Youdim, M. B. H., Grahame-Smith, D. G. Woods, H. F. (1976). Clin. Sci. mol. Med. 50, 479.

Youdim, M. B. H., Woods, H. F., Mitchell, B., Grahame-Smith, D. G. \& Callender, S. (r975). Clin. Sci. mol. Med. 48, 289. 